\title{
Disease control and objective responsive rates in randomized phase II trials evaluating non-first-line chemotherapy for non- small cell lung cancer: a systematic review of 74 trials
}

\author{
Hiromi Matsumoto ${ }^{1}$, Nobuyuki Horita ${ }^{1}$, Kentaro Ito ${ }^{2}$, Risa Ebina-Shibuya ${ }^{3}$, Yu Hara ${ }^{1}$, Nobuaki Kobayashi ${ }^{1}$, \\ Takeshi Kaneko ${ }^{1}$ \\ ${ }^{1}$ Department of Pulmonology, Yokohama City University Graduate School of Medicine. Yokohama, Japan; ${ }^{2}$ Respiratory Center, Matsusaka Municipal \\ Hospital, Matsusaka, Japan; ${ }^{3}$ Pediatric Oncology Branch, National Cancer Institute, National Institutes of Health, Bethesda, MD, USA \\ Contributions: (I) Conception and design: N Horita, K Ito; (II) Administrative support: T Kaneko; (III) Provision of study materials or patients: None; \\ (IV) Collection and assembly of data: H Matsumoto, N Horita, R Ebina-Shibuya; (V) Data analysis and interpretation: H Matsumoto, N Horita, K \\ Ito, Y Hara, N Kobayashi, T Kaneko; (VI) Manuscript writing: All authors; (VII) Final approval of manuscript: All authors. \\ Correspondence to: Nobuyuki Horita, MD, PhD. Department of Pulmonology, Yokohama City University Graduate School of Medicine, 3-9 Fukuura, \\ Kanazawa-ku, Yokohama, 236-0004, Japan. Email: horitano@yokohama-cu.ac.jp.
}

\begin{abstract}
Although objective response rate and disease control rate are commonly used as primary endpoints of lung cancer trials, it remains unclear whether objective response rate and disease control rate correctly reflect the overall survival in a non-small cell lung cancer phase II trial evaluating a non-firstline chemotherapy. Objective response rate might be easily affected by chance because the small number of patients in each trial achieved complete or partial response in the phase II non-first-line setting. This study was performed following the Preferred Reporting Items for Systematic Reviews and Meta-Analyses (UMIN000040412). Four databases were searched for eligible trials. A Spearman's rank correlation with hazard ratio of overall survival was calculated each for odds ratio of objective response rate, difference of objective response rate (\%), odds ratio of disease control rate, and difference of disease control rate (\%). Of 74 eligible trials, 73 reported objective response rate and 68 reported disease control rates. Nine (12\%) trials included patients with driver mutation status. Thirteen (18\%) and two (3\%) RCTs specifically included adenocarcinoma/non-squamous and squamous subtype of non-small cell lung cancer, respectively. The Eastern Cooperative Oncology Group performance status $0-2(\mathrm{~N}=41,55 \%)$ and the performance status 0-1 ( $\mathrm{N}=25,34 \%)$ were frequently used performance status criteria. The median number of patients in the two arms was 116 (interquartile range, 82-159). The correlation between trial-level odds ratio of objective response rate and hazard ratio of overall survival was weak ( $r=-0.29,95 \% \mathrm{CI}:-0.49$ to $-0.05, \mathrm{P}=0.014)$. An exploratory subgroup analysis suggested that fewer responders were associated with poorer correlation. Odds ratio of disease control survival ( $\mathrm{r}=-0.53,95 \% \mathrm{CI}$ : -0.68 to $-0.32, \mathrm{P}<0.001)$ had moderate rank correlations with hazard ratio of overall survival. Instead of objective response rate, disease control rate should be used as the primary endpoint in a randomized phase II trial evaluating non-first-line chemotherapy for non-small cell lung cancer.
\end{abstract}

Keywords: Lung neoplasm; response evaluation criteria in solid tumors; systematic review; correlation of data

Submitted Oct 16, 2020. Accepted for publication Feb 26, 2021.

doi: $10.21037 /$ tlcr-20-1120

View this article at: http://dx.doi.org/10.21037/tlcr-20-1120 


\section{Introduction}

Approximately two million individuals die from respiratory cancer every year (1). Non-small cell lung cancer (NSCLC), the leading pathological type of respiratory malignancy, accounts for $80 \%$ or more of respiratory cancer deaths in both sexes (2). Chemotherapies including immune checkpoint inhibitors and molecular targeted therapies play an important role in the treatment of incurable locally advanced, metastatic, and recurrent NSCLC. When relapse occurs after receiving first-line chemotherapy, a patient who maintains a reasonable performance status usually receives second-line chemotherapy. The efficacy and safety of chemotherapy in cancer patients are usually evaluated through phase I, II, and III trials. Once a phase I trial determines the dosage by safety assessment, a phase II trial is designed to test both the safety and efficacy of the treatment in a larger sample size. The best treatment efficacy outcome is overall survival (OS) as it is easy to interpret, indicates an ultimate benefit of a patient, and is not affected by an observational bias (3). However, researchers often select other indexes such as the objective response rate (ORR) and disease control rate (DCR) based on the Response Evaluation Criteria in Solid Tumors (RECIST) defined as primary endpoints of NSCLC phase II trial $(3,4)$. Besides, ORR may be a reasonable outcome to assess the potential anticancer activity of chemotherapy (5). The RECIST is a simple and useful tool that can be used to categorize patients with solid tumor who underwent chemotherapy into four groups: complete response (CR), partial response (PR), stable disease (SD), and progressive disease (PD). Currently, the revised RECIST guidelines are widely used in the clinical and research settings of a variety of solid tumors (5).

Although ORR and DCR are commonly used as primary endpoints (5), it remains unclear whether ORR and DCR correctly reflect the OS in a NSCLC phase II trial evaluating a non-first-line chemotherapy. ORR might be easily affected because the small number of patients in each trial achieved complete or partial response in the phase II non-first-line setting. In this study, we aimed to evaluate the association of trial-level ORR and DCR with OS in randomized phase II NSCLC trials that evaluate second- or later-line chemotherapy. We present the following article in accordance with the Preferred Reporting Items for Systematic Reviews and Meta-Analyses reporting checklist (available at http://dx.doi.org/10.21037/tlcr-20-1120).

\section{Methods}

\section{Study overview}

The current systematic review did not utilize a meta-analysis to aggregate data; however, this study was conducted following the Preferred Reporting Items for Systematic Reviews and Meta-Analyses as it is a reasonable method of performing a systematic review of RCTs (Table S1) (6). The protocol, UMIN000040412, has been registered on the website of the University Hospital Medical Information Network Clinical Trials Registration (7).

\section{Study search}

We systematically searched PubMed, Cochrane database, Embase, and Web of Science as of May 15, 2020 (6). The search formulas are presented elsewhere (Table S2). The reference list of all included articles was also manually checked. Two investigators independently screened the titles and abstracts and they also scrutinized the full text (HM and $\mathrm{NH}$ ). Repeated use of the same patient in duplicated studies was prohibited. If conflicts arise between the review authors during the selection of the final study, a discussion was made to resolve the inconsistencies.

\section{Study selection, design}

We included a phase II RCT that evaluated second- and/or later-line chemotherapy for advanced, locally advanced, and recurrent NSCLC $(8,9)$. An article had to be written as a full article, a brief report, or a conference abstract regardless of its primary end point. Non-English language reports were excluded. Randomized phase I/II trials were included. The protocol permitted a phase II/III trial when the data from phase II part could be extractable, but such a trial was not found.

\section{Study selection, patient}

Patients with a pathologically or cytologically confirmed diagnosis of locally advanced, advanced, and recurrent NSCLC who relapsed after one or more of previous chemotherapies were included. No limitation was set for age, sex, smoking history, first-line chemotherapy regimen, response to the first-line treatment, status of driver mutation, performance status, and pathological subtype of NSCLC. 


\section{Study selection, treatment}

A patient should be treated with any type of chemotherapeutic regimen including immune checkpoint inhibitors, molecular targeted therapy, cytotoxic agents, single drug regimens, and multi-drug regimens as nonfirst-line chemotherapy. Antibiotics and immunotherapy other than immune checkpoint inhibitors were not included because such treatment had never been considered as a standard therapy $(8,9)$. Comparison of the same drugs (low-dose versus high-dose, weekly versus tri-weekly regimens, and chemotherapy versus placebo) was allowed. Maintenance therapy after first-line chemotherapy was not considered as a second-line treatment as it was administered in a patient who did not experience a relapse. A trial with treatment crossover after the first-line therapy was excluded because such a trial randomized a patient prior to the firstline treatment.

\section{Assessment of the risk of bias}

The quality of each RCT was assessed using the six domains of Cochrane risk of bias (10).

\section{Outcomes}

The correlation, with hazard ratio (HR) of OS (HRos), each for odds ratio (OR) of ORR (ORorr), difference of ORR $(\triangle \mathrm{ORR}, \%)$, OR of DCR (ORdcr), and difference of DCR $(\triangle \mathrm{DCR}, \%)$ was evaluated. $\triangle \mathrm{ORR}$ was calculated by subtracting the ORR estimated for the second treatment arm from that estimated for the first arm. Similarly, $\triangle \mathrm{DCR}$ was obtained. CR, PR, and SD needed to be evaluated in line with the RECIST 2000 and the revised RECIST 2009 revised guidelines (5). When an article reported that the RECIST outcome was judged by both investigator team and an independent radiographic review panel, the data of the external panel was adopted.

\section{Data extraction}

Data regarding the study characteristics, OS, ORR, DCR, and risk of bias were independently extracted by the two review investigators ( $\mathrm{HM}$ and $\mathrm{NH}$ ). Once the review authors extracted inconsistent data, a discussion is made to reach consensus. The first and second arms of each RCT were decided according to the description in each article. When a study randomized patients into three or more arms, two arms with the largest number of patients were selected for our analysis. ORR and DCR were preferably determined by full analysis set or intention-to-treat analysis; thus, a denominator to yield ORR and DCR included patients whose data were not assessable by RECIST (5). Parmar's method was applied to obtain OS data from the KaplanMeier curves as necessary (11). We respected the authors' judgement of disease staging regardless of the updates of TNM staging system. For example, a patient with pleural effusion without metastasis might be diagnosed with stage IIIb or IV based on the trial policy.

\section{Statistical analysis}

Spearman's rank correlation coefficient (r) was calculated using GraphPad PRISM ver 7.02 (San Diego, CA, USA). When one or more cells in the two-by-two contingency used to calculate ORorr and ORdcr were null, a continuity correction with 0.5 was applied. A correlation coefficient was interpreted as follows: $|\mathrm{r}|<0.2$, no correlation; $0.2<|\mathrm{r}|$ $<0.4$, weak correlation; $0.4<|\mathrm{r}|<0.6$, moderate correlation; $0.6<|\mathrm{r}|<0.8$, strong correlation; and $0.8<|\mathrm{r}|$, excellent correlation. The statistical significance threshold was set at $\mathrm{P}<0.05$. The Begg-Kendall test was carried out to assess for publication bias. The correlation was displayed on a scatter plot.

Exploratory subgroup analyses were performed by classifying studies by characteristics such as sample size and number of responders with a median as the cutoff of subgroups.

\section{Results}

\section{Study search}

Out of 1,437 articles that were identified by database search and hand searches, 73 met our inclusion criteria (Table S2). Since one article represented two independent RCTs, we analyzed 74 trials that randomized NSCLC patients for second- or later- line chemotherapy (Figure 1, Table 1, Appendix References).

\section{Study characteristics}

The study characteristics of each study are summarized in Table 1, and aggregated data are presented in Table 2. The majority of these trials were reported as full-length articles that compared two arms with clear declaration of phase 


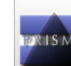

PRISMA 2009 Flow Diagram
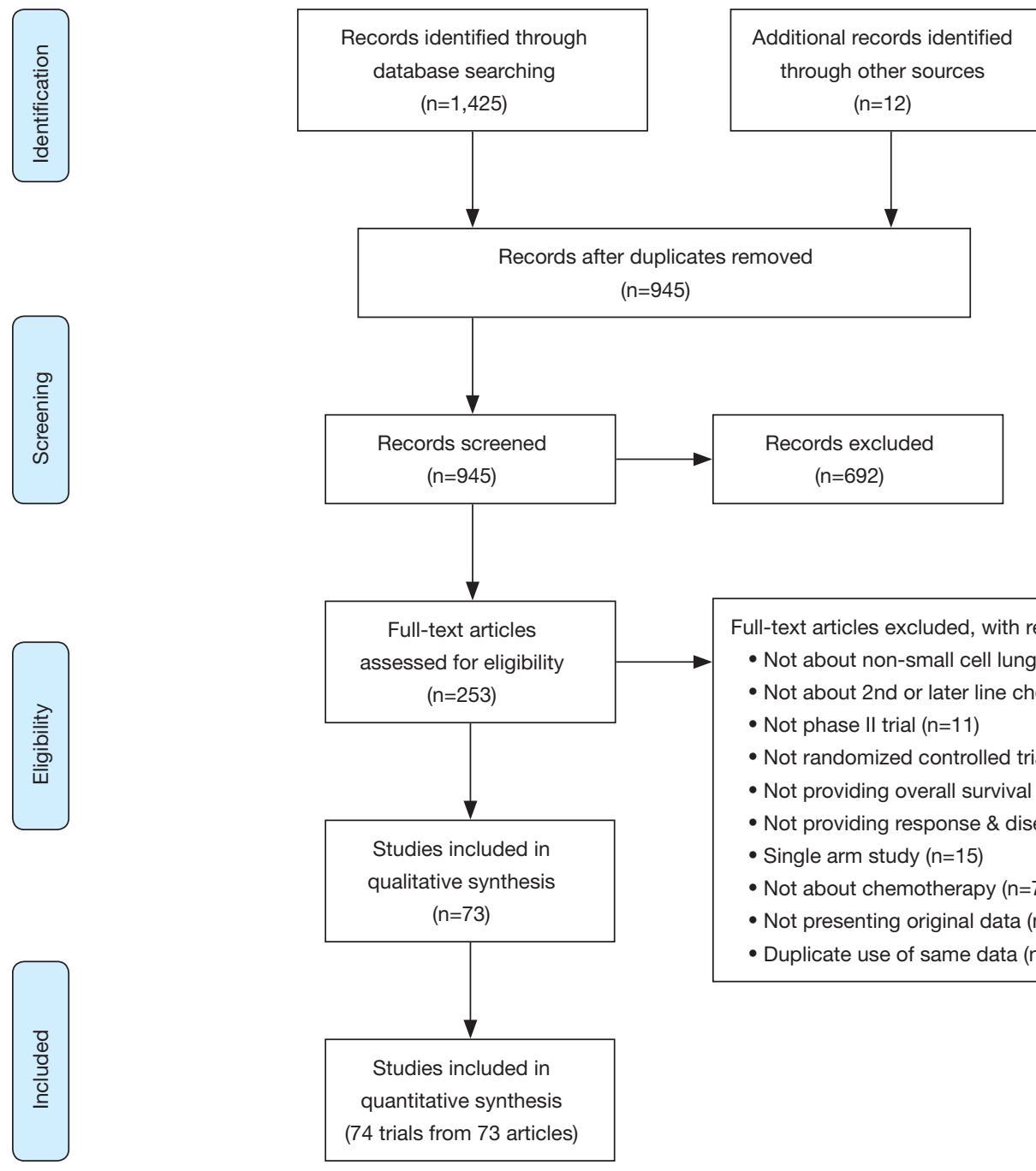

Full-text articles excluded, with reasons $(n=180)$

- Not about non-small cell lung cancer $(n=7)$

- Not about 2 nd or later line chemotherapy $(n=16)$

- Not phase II trial $(n=11)$

- Not randomized controlled trial $(n=4)$

- Not providing overall survival hazard ratio $(n=24)$

- Not providing response \& disease control data $(n=2)$

- Single arm study $(n=15)$

- Not about chemotherapy $(n=7)$

- Not presenting original data $(n=18)$

- Duplicate use of same data $(n=76)$

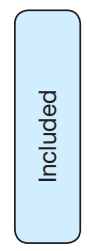

Figure 1 Preferred Reporting Items for Systematic Reviews and Meta-Analyses (PRISMA) flow chart.

II except three conference abstracts, one brief report, ten three-arm trials, two four-arm trials, and one phase Ib/II trial. These 74 trials were reported from European $(\mathrm{N}=33)$, North American $(\mathrm{N}=21)$, and Asian $(\mathrm{N}=20)$ countries. Thirteen (18\%) and two (3\%) RCTs recruited patients with adenocarcinoma/non-squamous and squamous cell carcinoma, respectively, while the other 59 (80\%) RCTs randomized non-small cell lung cancer patients without specifying a pathological subtype of NSCLC (Table 2).
A total of $65(88 \%)$ RCTs did not recruit patients with specific driver mutation status. The most frequently used primary endpoint was progression-free survival (PFS) $(\mathrm{N}=36,49 \%)$ followed by ORR ( $\mathrm{N}=15,20 \%)$. Only two studies (3\%) used DCR as the primary endpoint. More than two-thirds (N=51, 69\%) of trials focused on second-line chemotherapy. The widely used performance status criteria were Eastern Cooperative Oncology Group (ECOG) 0-2 $(\mathrm{N}=41,55 \%)$ and ECOG $0-1(\mathrm{~N}=25,34 \%)$. The median 


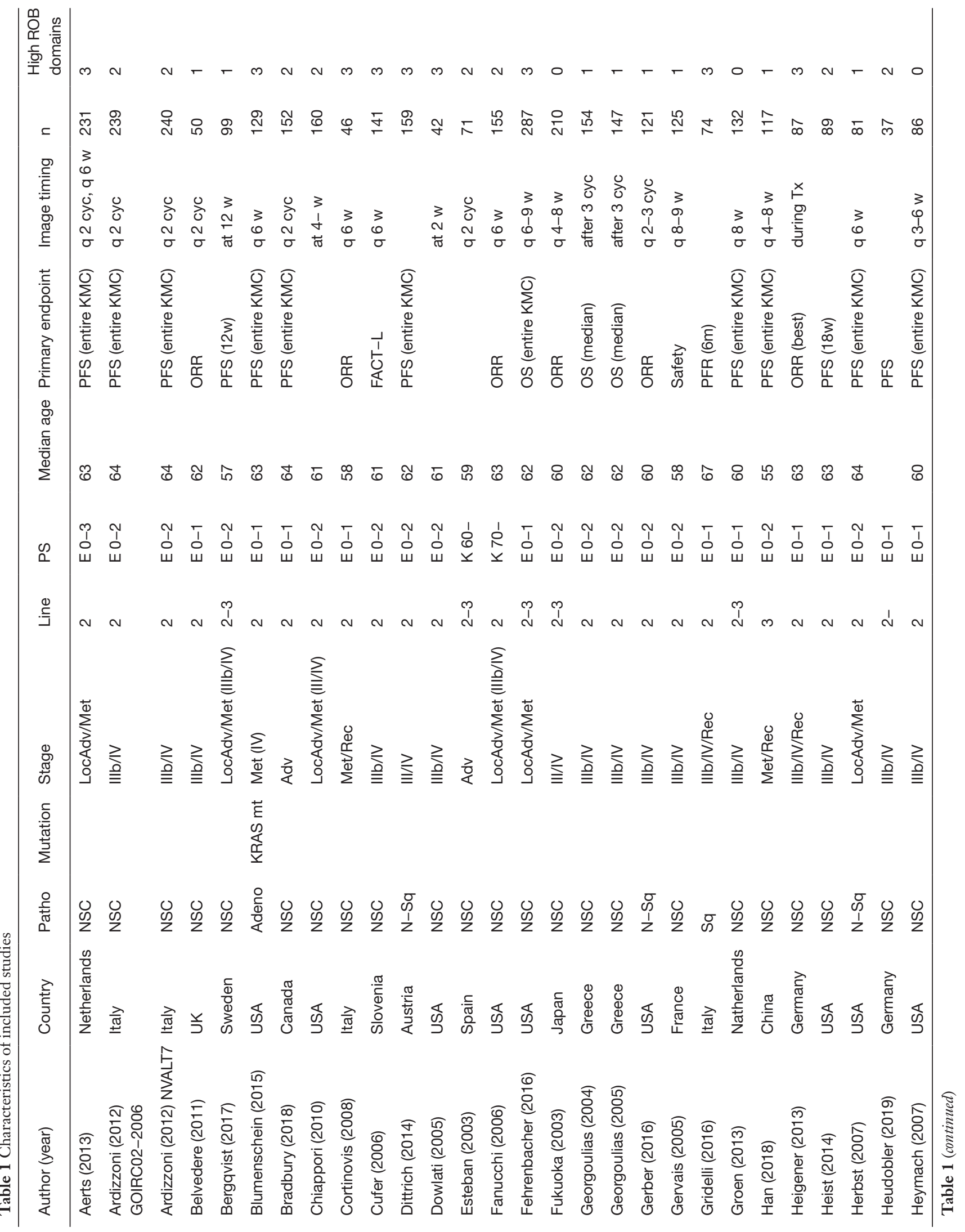




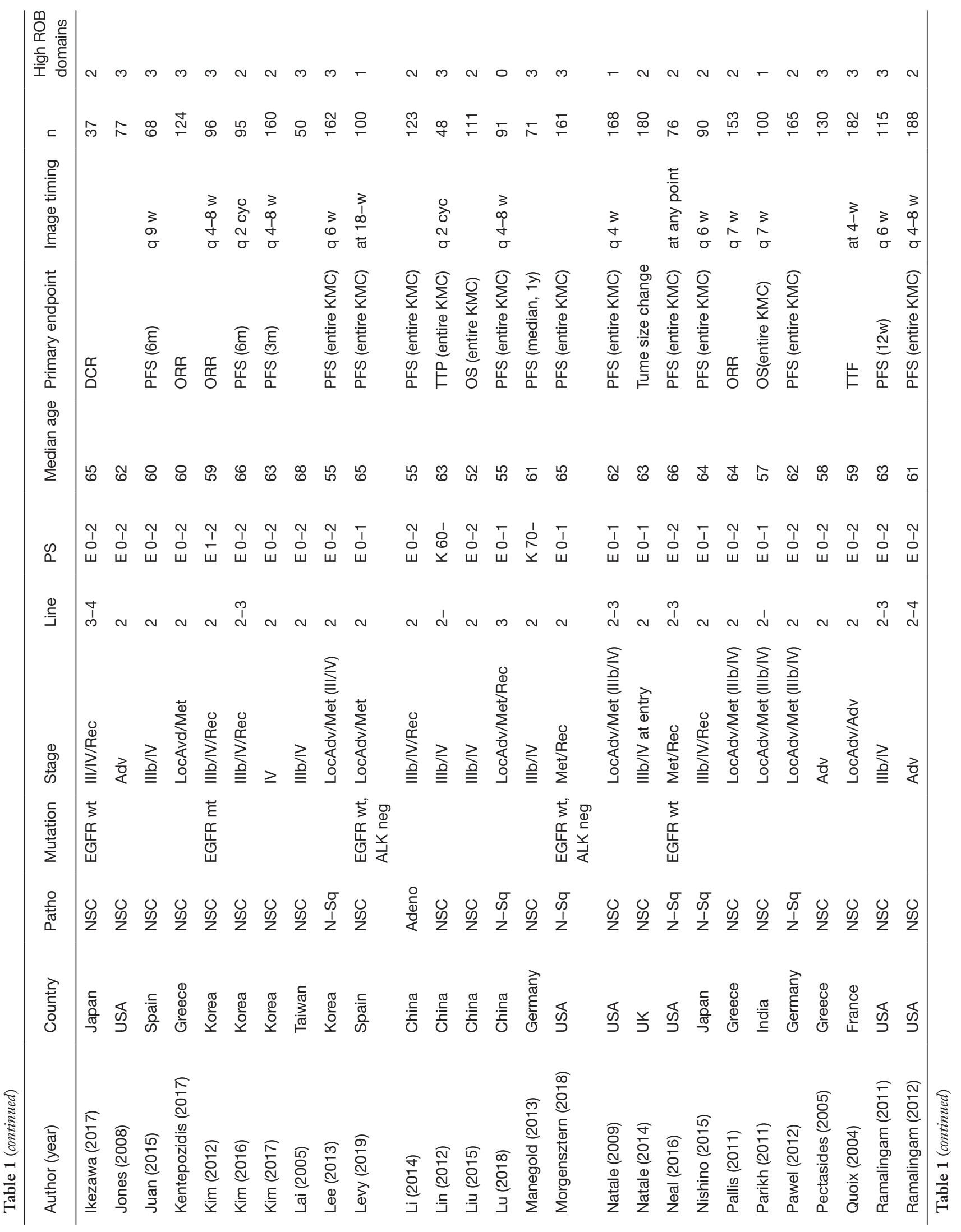




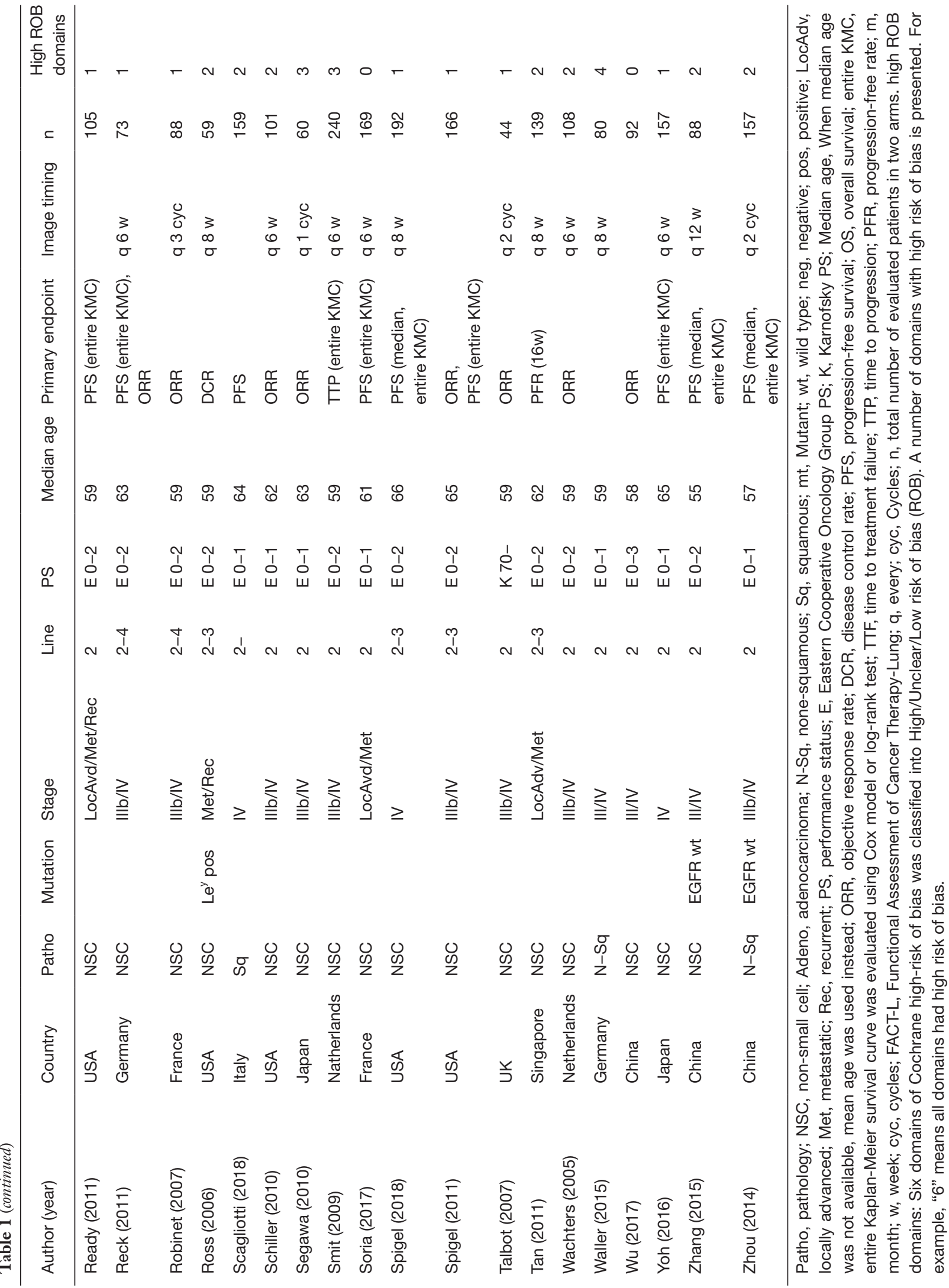


Table 2 Study level summary statistics of 74 included studies

\begin{tabular}{|c|c|}
\hline Publication year & 2012 (2008-2016) \\
\hline \multicolumn{2}{|l|}{ Pathological type } \\
\hline Non-small cell & $59(80 \%)$ \\
\hline Adenocarcinoma or non-squamous & $13(18 \%)$ \\
\hline Squamous & $2(3 \%)$ \\
\hline \multicolumn{2}{|l|}{ Driver mutation } \\
\hline Not specified & $65(88 \%)$ \\
\hline EGFR mutant & $1(1 \%)$ \\
\hline KRAS mutant & $1(1 \%)$ \\
\hline LyS positive & $1(1 \%)$ \\
\hline EGFR wild type & $4(5 \%)$ \\
\hline EGFR wild type and ALK negative & $2(3 \%)$ \\
\hline \multicolumn{2}{|l|}{ Primary endpoint } \\
\hline Objective response rate (ORR) & $15(20 \%)$ \\
\hline Disease control rate & $2(3 \%)$ \\
\hline Overall survival & $5(7 \%)$ \\
\hline Progression-free survival (PFS) & $36(49 \%)$ \\
\hline Progression-free rate & $2(3 \%)$ \\
\hline Time-to-failure, time-to-progression & $3(4 \%)$ \\
\hline Co-primary ORR and PFS & $1(1 \%)$ \\
\hline Other (symptom, safety, tumor size change) & $3(4 \%)$ \\
\hline Not specified & $7(9 \%)$ \\
\hline \multicolumn{2}{|l|}{ Chemotherapy line } \\
\hline 2 & $51(69 \%)$ \\
\hline $2-3$ & $13(18 \%)$ \\
\hline $2-4$ & $3(4 \%)$ \\
\hline $2-$ & $4(5 \%)$ \\
\hline 3 & $2(3 \%)$ \\
\hline $3-4$ & $1(1 \%)$ \\
\hline \multicolumn{2}{|l|}{ Performance status (PS) } \\
\hline Eastern Cooperative Oncology Group PS 0-1 & $25(34 \%)$ \\
\hline Eastern Cooperative Oncology Group PS 0-2 & $41(55 \%)$ \\
\hline Eastern Cooperative Oncology Group PS 0-3 & $2(3 \%)$ \\
\hline Karnofsky PS 60- & $2(3 \%)$ \\
\hline Karnofsky PS 70- & $3(4 \%)$ \\
\hline
\end{tabular}

Table 2 (continued)
Table 2 (continued)

\begin{tabular}{lc}
\hline Publication year & $2012(2008-2016)$ \\
\hline Median age & $62[59-63]$ \\
N of patients in both arms & $116[82-159]$ \\
N of patients with response in both arms & $13[6-22]$ \\
N of patients with disease control in both arms & $56[36-77]$ \\
\hline
\end{tabular}

For a bivariate and a nominal variable, number of studies and percentage are presented. For a continuous variable, a median and an interquartile range are presented. Sum of percentage is not always $100 \%$ due to rounding.

number of patients in the two arms was 116 [interquartile range (IQR), 82-159]. Single-agent docetaxel was the most frequently used treatment arm (23 arms) followed by single-agent pemetrexed (14 arms) and erlotinib alone (14 arms) probably because this regimen was used as a standard second-line regimen over the years (Table 1) $(9,12)$. Treatments prior to each study was inconsistent. Sixty-eight studies (92\%) had at least one domain of risk of bias (Table 1, Table S3). The key outcomes of each trial are also presented in elsewhere (Table S4).

\section{ORR and DCR}

Most studies described the ORR and DCR data but five only reported ORR and one only reported DCR (Table S4). Among the 146 arms from 73 studies, the median ORR was $11 \%$ (IQR, 5-17), which resulted in a median number of responders $(\mathrm{CR}+\mathrm{PR})$ in each study of 13 (IQR, 6-22) patients. The median number of patients with disease control $(\mathrm{CR}+\mathrm{PR}+\mathrm{SD})$ in the 136 arms from 68 RCTs was 56 (IQR, 36-77). The median DCR was $51 \%$. No publication bias was found in either the ORR or DCR (Figure S1).

\section{Correlation between ORR and OS}

The Spearman's correlation between trial-level ORorr and HRos was weak ( $\mathrm{r}=-0.29,95 \% \mathrm{CI}:-0.49$ to $-0.05, \mathrm{P}=0.014$, Figure 2). $\triangle \mathrm{ORR}$ also had a weak correlation with HRos $(\mathrm{r}=-0.33,95 \%$ CI: -0.52 to $-0.10, \mathrm{P}=0.005$ ) (Figure $\mathrm{S} 2$ ).

The exploratory subgroup analyses between ORorr and HRos suggested a prominent inter-subgroup difference in responder-based analysis. No correlation $(|\mathrm{r}|<0.2)$ was 

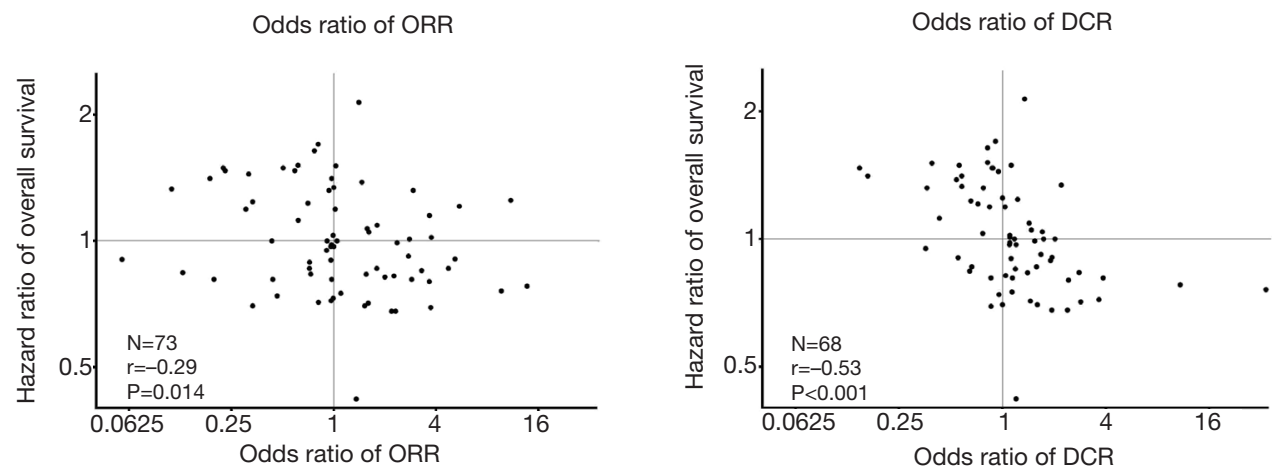

Figure 2 Trial-level surrogacy: odds ratio of objective response rate (ORR) and disease control rate (DCR). N, number of trials. $\mathrm{r}$, Spearman's rank correlation coefficient. A correlation coefficient was interpreted as follows: $|\mathrm{r}|<0.2$, no correlation; $0.2<|\mathrm{r}|<0.4$, weak correlation; $0.4<|\mathrm{r}|<0.6$, moderate correlation; $0.6<|\mathrm{r}|<0.8$, strong correlation; and $0.8<|\mathrm{r}|$, excellent correlation.

observed in the "responders, -10 " subgroup ( $\mathrm{r}=-0.15,95 \%$ CI: -0.47 to $0.21, \mathrm{P}=0.403$, Figure 3 ) while that in the "responders, 11-" subgroup was moderate $(\mathrm{r}=-0.51,95 \%$ CI: -0.72 to $-0.22, \mathrm{P}<0.001$, Figure 3).

\section{Correlation between DCR and OS}

Both ORder ( $\mathrm{r}=-0.53,95 \% \mathrm{CI}:-0.68$ to $-0.32, \mathrm{P}<0.001$, Figure 2) and $\triangle \mathrm{DCR}$ ( $\mathrm{r}=-0.52,95 \% \mathrm{CI}:-0.68$ to -0.31 , $\mathrm{P}<0.001$, Figure S2) had a moderate rank correlation with HRos. Compared with ORorr, ORder had the same or higher-level correlation with HRos in any subgroup analyses (Figure 3).

\section{Discussion}

In the assessment of the efficacy of chemotherapy in solid malignancies, tumor shrinkage judged by ORR has traditionally been regarded as a proxy of clinical benefit and prolonged survival (13) partially because the response indicates the anticancer activity of chemotherapy (5). Thus, ORR was the preferred outcome rather than DCR in the chemotherapy trials. A total of 15 (20\%) out of 74 phase II trials in our analysis adopted ORR as the primary endpoint, while only 2 (3\%) selected DCR (Table 2). In this study, we assessed the correlation of ORR and DCR with HRos at trial level in randomized phase II trials that evaluated second- or later-line chemotherapy for NSCLC. ORder $(\mathrm{r}=-0.53, \mathrm{P}<0.001)$ and $\triangle \mathrm{DCR}(\mathrm{r}=-0.52$, $\mathrm{P}<0.001)$ moderately correlated with HRos; however, ORorr $(\mathrm{r}=-0.29, \mathrm{P}=0.014)$ and $\triangle \mathrm{ORR}(\mathrm{r}=-0.33, \mathrm{P}=0.005)$ had weak correlations (Figure 2). If ORR and DCR capture some patient-oriented benefits such as survival and quality of life, they can be useful study endpoints. Otherwise, the application of these endpoints might be questionable because no imaging modality offers a straightforward measurement of patient-oriented benefits (3,14-16). Even though a chemotherapy regimen with both favorable ORR and poor survival can pass the phase II trial that adopts ORR as the primary endpoint, such treatment cannot meet the primary OS endpoint of phase III trials. By contrast, regimens such as atezolizumab that lead to prolonged survival without good response should be highly recognized $(17,18)$. Data on ORR and DCR are always simultaneously reported. Given the better trial-level association between DCR and survival, DCR seems to be a superior outcome in the phase II trial evaluating non-first-line chemotherapy for NSCLC. Although the current analysis included only RCTs, DCR may also be a reasonable outcome in a singlearm phase II trial. In addition to the better surrogacy of OS, broader applicability for patients without measurable disease is another advantage of DCR (13) because a trial that adopted ORR as the primary endpoint should recruit patients with at least one measurable lesion.

ORR is more frequently selected as the study endpoint compared with DCR (Table 2); however, some published studies have indicated that DCR is a more accurate surrogate of OS. Lara et al. gathered data of nearly 1,000 NSCLC patients from three RCTs for platinum-based chemotherapy (13). Although patients with response, $\mathrm{CR}+\mathrm{PR}$, led longer survival with a $\mathrm{HR}$ of 0.61 , maintaining at least stable disease, $\mathrm{CR}+\mathrm{PR}+\mathrm{SD}$, was a stronger predictor of OS with a HR of 0.45 . Half of the trials in our review adopted PFS as the primary endpoint (Table 2). PFS 
A Objective response rate

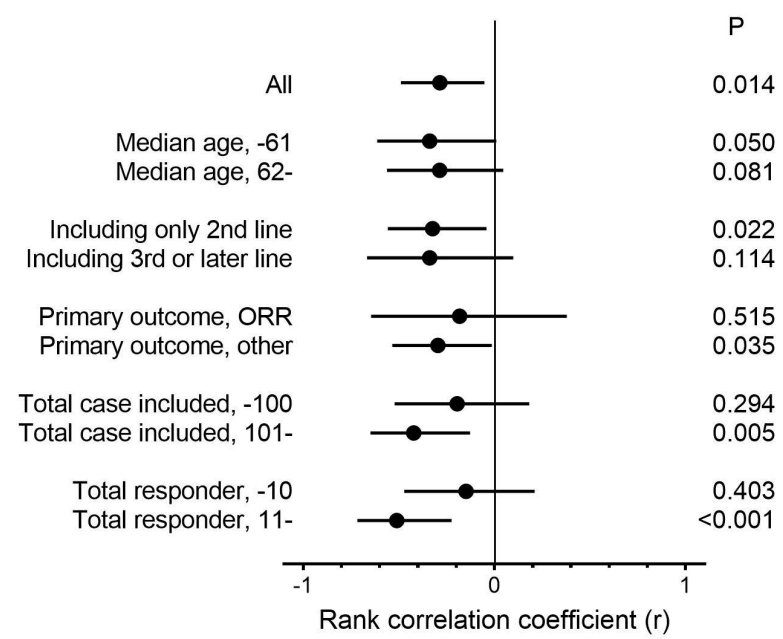

B Disease control rate

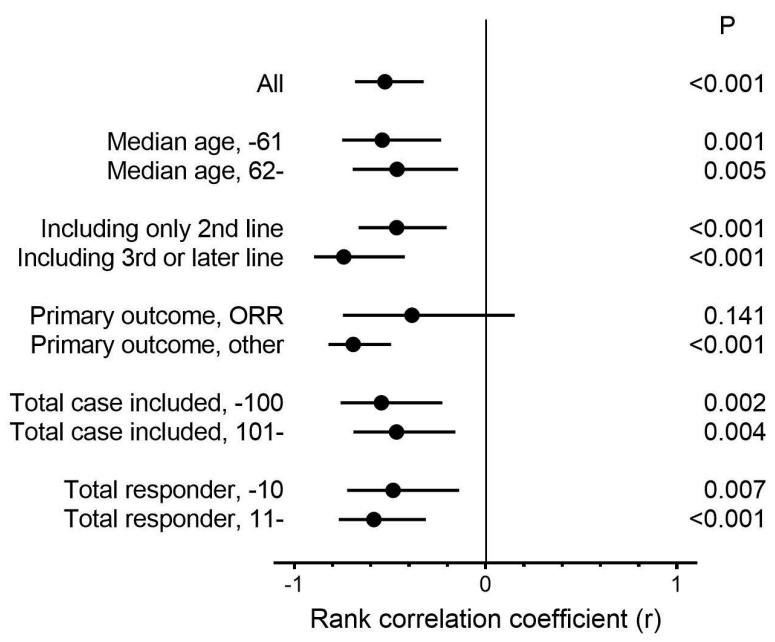

Figure 3 Subgroup analysis of trial-level correlations with overall survival. (A) Subgroup analysis of trial-level correlations between objective response rate and hazard ratio of overall survival. (B) Subgroup analysis of trial-level correlations between disease control rate and hazard ratio of overall survival. $r$ : Spearman's rank correlation coefficient. A correlation coefficient was interpreted as follows: $|r|<0.2$, no correlation; $0.2<|r|<0.4$, weak correlation; $0.4<|r|<0.6$, moderate correlation; $0.6<|r|<0.8$, strong correlation; and $0.8<|r|$, excellent correlation. Responder is a sum of complete response and partial response.

resembles DCR since response is not necessary, while ORR and response duration require at least PR. Mandrekar et al. analyzed the individual data of 284 patients with NSCLC enrolled in phase II trials (4). They concluded that PFS at 12 weeks, a similar metric to DCR, more accurately predicted subsequent survival compared with tumor response. The methodology of our study evaluating trial-level association was different from that of previous studies $(4,13)$. However, our conclusion was consistent with the conclusions of these preceding analyses. The better surrogacy of DCR was confirmed for solid tumors other than NSCLC. Lara et al. retrospectively analyzed the data of 263 extensive small-cell lung cancer patients from phase II trials in 2016 (19). In this setting, DCR (HR 0.45) was a more prominent surrogate of OS than ORR (HR 0.74). DCR was also more tightly linked to the trial-level OS of advanced colorectal cancer in the first-line setting than ORR (DCR, $r=0.975, \mathrm{R}^{2}=0.889$; ORR, $\mathrm{r}=0.866, \mathrm{R}^{2}=0.484$ ).

We would like to consider why ORR did not reflect survival in a phase II RCT of non-first-line chemotherapy for NSCLC. First, ORR overrates "aggressive" chemotherapy, such as a high-dose regimen and a combination treatment. Aggressive chemotherapeutic treatment damages both tumor cells and normal cells, which results in good ORR and deteriorated organ function. Once ORR is chosen as the primary endpoint, a researcher might be motivated to use excessively aggressive chemotherapies. Choosing an aggressive regimen as second-line chemotherapy is especially risky because toxicity caused by first-line treatment already affected the patient's organ function. The optimal endpoint might be inconsistent between the first-line and the later-line treatments. Our previous analysis indicated that the ORR of the first-line NSCLC chemotherapy better predicts OS than DCR (3). A chemo-naive patient can endure an aggressive chemotherapy, and a chemo-naive tumor lesion is usually more responsive to an anti-tumor medication. Selecting an aggressive regimen with capable anticancer activity that yields high ORR is a feasible choice for firstline RCT but not a reasonable strategy for a later-line trial. The second possibility is that ORR might be unreliable due the small number of responders in the second- or latter-line phase II setting (19). In the explanatory subgroup analysis, no correlation was observed between ORR and OS in the "responder-10" subgroup, while moderate correlation was found in the "responder 11-" subgroup (Figure 3). DCR may be a reliable outcome because of the higher event frequency. 
ORR is a popular endpoint in phase II non-first-line trials for solid tumors other than NSCLC. Nonetheless, we suspect that DCR more accurately reflects OS in these trials because patients are often exhausted after receiving first-line treatment and there are usually few responders in the non-first-line phase II trial regardless of malignancy type. The trial-level correlation between ORR and OS in phase II second-line trials should be evaluated for other malignancies such as colorectal cancer because the ORR of the second-line chemotherapy for these types of cancers is as low as that for NSCLC $(20,21)$.

Even though DCR better reflected OS than ORR, the surrogacy of DCR was still unsatisfactory. Late PFS, such as 6-month PFS, might be a more accurate surrogate of OS than DCR in studies with a longer follow-up duration. OS data directly demonstrate the patient's benefit, although it requires further longer follow-up to aggregate the number of events. In principle, longer follow-up is not recommended in a phase II trial as a phase II trial is just a screening process to select a regimen that will be assessed in a phase III trial. There is always a tradeoff between promptness and outcome value when selecting a phase II trial endpoint.

This study has some limitations. First, although OS is the gold standard endpoint of an advanced NSCLC trial, OS may be easily affected by later-line treatment. Nonetheless, this issue did not make our analysis unreliable because successive chemotherapy after the non-first-line treatment cannot largely provide survival benefit. Second, the current consensus recommends that NSCLC patients should be treated based on pathological subtype and driver mutation status $(8,9)$; however, most of the included studies did not mention these data. Third, we analyzed studies adopted cytotoxic agent, MMT, ICI, and combination of them collectively. Fourth, PFS-related analysis could not be performed due to inconsistent PFS data format from the trials including 2-month PFS, median PFS, hazard ratio of PFS, P value from log-rank test. Fifth, most of studies recruited patients with inconsistent prior treatments.

In conclusion, we systematically searched for randomized phase II trials that evaluated second- or later-line chemotherapy for NSCLC. ORR is a more frequently used as a primary endpoint than DCR (Table 2). According to 68 trials, DCR had moderate trial-level correlations (ORder $\mathrm{r}=-0.53, \Delta \mathrm{DCR} \mathrm{r}=-0.52$ ) with HRos while ORorr and $\triangle$ ORR had weak correlations (ORorr $\mathrm{r}=-0.29, \Delta \mathrm{ORR}$ $\mathrm{r}=-0.33)$. The subgroup analysis suggested that the rarity of responders in the phase II non-first-line setting may lead to the poor association between ORR and HRos. Since data on ORR and DCR are available simultaneously, we recommend using DCR instead of ORR as the primary endpoint in a randomized phase II trial evaluating secondor later-line chemotherapy for NSCLC.

\section{Acknowledgments}

Funding: None.

\section{Footnote}

Reporting Checklist: The authors have completed the PRISMA reporting checklist. Available at http://dx.doi. org/10.21037/tlcr-20-1120

Conflicts of Interest: All authors have completed the ICMJE uniform disclosure form (available at http://dx.doi. org/10.21037/tlcr-20-1120). The authors have no conflicts of interest to declare.

Ethical Statement: The authors are accountable for all aspects of the work in ensuring that questions related to the accuracy or integrity of any part of the work are appropriately investigated and resolved.

Open Access Statement: This is an Open Access article distributed in accordance with the Creative Commons Attribution-NonCommercial-NoDerivs 4.0 International License (CC BY-NC-ND 4.0), which permits the noncommercial replication and distribution of the article with the strict proviso that no changes or edits are made and the original work is properly cited (including links to both the formal publication through the relevant DOI and the license). See: https://creativecommons.org/licenses/by-nc-nd/4.0/.

\section{References}

1. Fitzmaurice C, Abate D, Abbasi N, et al. Global, Regional, and National Cancer Incidence, Mortality, Years of Life Lost, Years Lived With Disability, and DisabilityAdjusted Life-Years for 29 Cancer Groups, 1990 to 2017: A Systematic Analysis for the Global Burden of Disease Study. JAMA Oncol 2019;5:1749-68.

2. Molina JR, Yang P, Cassivi SD, et al. Non-small cell lung cancer: epidemiology, risk factors, treatment, and survivorship. Mayo Clin Proc 2008;83:584-94.

3. Nakashima K, Horita N, Nagai K, et al. Progression- 
Free Survival, Response Rate, and Disease Control Rate as Predictors of Overall Survival in Phase III Randomized Controlled Trials Evaluating the First-Line Chemotherapy for Advanced, Locally Advanced, and Recurrent Non-Small Cell Lung Carcinoma. J Thorac Oncol 2016;11:1574-85.

4. Mandrekar SJ, Qi Y, Hillman SL, et al. Endpoints in phase II trials for advanced non-small cell lung cancer. J Thorac Oncol 2010;5:3-9.

5. Eisenhauer EA, Therasse P, Bogaerts J, et al. New response evaluation criteria in solid tumours: revised RECIST guideline (version 1.1). Eur J Cancer 2009;45:228-47.

6. Moher D, Liberati A, Tetzlaff J, et al. Preferred reporting items for systematic reviews and meta-analyses: the PRISMA statement. BMJ 2009;339:b2535.

7. University hospital Medical Information Network Center. University hospital Medical Information Network Center Clinical Trial Registry. Accessed on June 15, 2020. Available online: https://www.umin.ac.jp/ctr/index-j.htm.

8. Reck M, Rabe KF. Precision Diagnosis and Treatment for Advanced Non-Small-Cell Lung Cancer. N Engl J Med 2017;377:849-61.

9. Zappa C, Mousa SA. Non-small cell lung cancer: current treatment and future advances. Transl Lung Cancer Res 2016;5:288-300.

10. Higgins JP, Altman DG, Gøtzsche PC, et al. The Cochrane Collaboration's tool for assessing risk of bias in randomised trials. BMJ 2011;343:d5928.

11. Parmar MK, Torri V, Stewart L. Extracting summary statistics to perform meta-analyses of the published literature for survival endpoints. Stat Med 1998;17:2815-34.

12. Fossella FV, DeVore R, Kerr RN, et al. Randomized phase III trial of docetaxel versus vinorelbine or ifosfamide in patients with advanced non-small-cell lung cancer previously treated with platinum-containing chemotherapy regimens. The TAX 320 Non-Small Cell Lung Cancer Study Group. J Clin Oncol 2000;18:2354-62.

13. Lara PN, Jr., Redman MW, Kelly K, et al. Disease control rate at 8 weeks predicts clinical benefit in advanced nonsmall-cell lung cancer: results from Southwest Oncology Group randomized trials. J Clin Oncol 2008;26:463-7.

14. De Gruttola VG, Clax P, DeMets DL, et al.

Considerations in the evaluation of surrogate endpoints in clinical trials: Summary of a National Institutes of Health Workshop. Control Clin Trials 2001;22:485-502.

15. Fleming TR, Powers JH. Biomarkers and surrogate endpoints in clinical trials. Stat Med 2012;31:2973-84.

16. Lesko LJ, Atkinson AJ. Use of biomarkers and surrogate endpoints in drug development and regulatory decision making: Criteria, validation, strategies. Annu Rev Pharmacol Toxicol 2001;41:347-66.

17. Fehrenbacher L, Spira A, Ballinger M, et al. Atezolizumab versus docetaxel for patients with previously treated non-small-cell lung cancer (POPLAR): a multicentre, open-label, phase 2 randomised controlled trial. Lancet 2016;387:1837-46

18. Gandara DR, von Pawel J, Mazieres J, et al. Atezolizumab Treatment Beyond Progression in Advanced NSCLC: Results From the Randomized, Phase III OAK Study. J Thorac Oncol 2018;13:1906-18.

19. Lara PN Jr, Moon J, Redman MW, et al. Disease Control Rate at 8 Weeks Predicts Subsequent Survival in PlatinumTreated Extensive Stage Small-Cell Lung Cancer: Results From the Southwest Oncology Group (SWOG) Database. Clin Lung Cancer 2016;17:113-118.e111-2.

20. Chibaudel B, Maindrault-Goebel F, Bachet JB, et al. PEPCOL: a GERCOR randomized phase II study of nanoliposomal irinotecan PEP02 (MM-398) or irinotecan with leucovorin/5-fluorouracil as second-line therapy in metastatic colorectal cancer. Cancer Med 2016;5:676-83.

21. Kuramochi H, Ando M, Itabashi M, et al. Phase II study of bevacizumab and irinotecan as second-line therapy for patients with metastatic colorectal cancer previously treated with fluoropyrimidines, oxaliplatin, and bevacizumab. Cancer Chemother Pharmacol 2017;79:579-85.
Cite this article as: Matsumoto H, Horita N, Ito K, EbinaShibuya R, Hara Y, Kobayashi N, Kaneko T. Disease control and objective responsive rates in randomized phase II trials evaluating non-first-line chemotherapy for non-small cell lung cancer: a systematic review of 74 trials. Transl Lung Cancer Res 2021;10(5):2278-2289. doi: 10.21037/tlcr-20-1120 


\section{References}

22. Aerts JG, Codrington H, Lankheet NA, et al. A randomized phase II study comparing erlotinib versus erlotinib with alternating chemotherapy in relapsed nonsmall-cell lung cancer patients: the NVALT-10 study. Ann Oncol 2013;24:2860-65.

23. Ardizzoni A, Tiseo M, Boni L, et al. Pemetrexed versus pemetrexed and carboplatin as second-line chemotherapy in advanced non-small-cell lung cancer: results of the GOIRC 02-2006 randomized phase II study and pooled analysis with the NVALT7 trial. J Clin Oncol 2012;30:4501-7.

24. Belvedere O, Follador A, Rossetto C, et al. A randomised phase II study of docetaxel/oxaliplatin and docetaxel in patients with previously treated non-small cell lung cancer: an Alpe-Adria Thoracic Oncology Multidisciplinary group trial (ATOM 019). Eur J Cancer 2011;47:1653-9.

25. Bergqvist M, Holgersson G, Bondarenko I, et al. Phase II randomized study of the IGF-1R pathway modulator AXL1717 compared to docetaxel in patients with previously treated, locally advanced or metastatic nonsmall cell lung cancer. Acta Oncol 2017;56:441-7.

26. Blumenschein GR, Jr., Smit EF, Planchard D, et al. A randomized phase II study of the MEK1/MEK2 inhibitor trametinib (GSK1120212) compared with docetaxel in KRAS-mutant advanced non-small-cell lung cancer (NSCLC)†. Ann Oncol 2015;26:894-901.

27. Bradbury PA, Morris DG, Nicholas G, et al. Canadian Cancer Trials Group (CCTG) IND211: A randomized trial of pelareorep (Reolysin) in patients with previously treated advanced or metastatic non-small cell lung cancer receiving standard salvage therapy. Lung Cancer 2018;120:142-8.

28. Chiappori A, Bepler G, Barlesi F, et al. Phase II, doubleblinded, randomized study of enzastaurin plus pemetrexed as second-line therapy in patients with advanced non-small cell lung cancer. J Thorac Oncol 2010;5:369-75.

29. Cortinovis D, Bidoli $\mathrm{P}$, Cullurà D, et al. Is irinotecan plus docetaxel useful as second-line therapy in advanced nonsmall cell lung cancer? J Thorac Oncol 2008;3:405-411.

30. Cufer T, Vrdoljak E, Gaafar R, Erensoy I, Pemberton K, grp Ss. Phase II, open-label, randomized study (SIGN) of single-agent gefitinib (IRESSA) or docetaxel as second-line therapy in patients with advanced (stage IIIb or IV) nonsmall-cell lung cancer. Anticancer Drugs 2006;17:401-9.

31. Dittrich C, Papai-Szekely Z, Vinolas N, et al. A randomised phase II study of pemetrexed versus pemetrexed+erlotinib as second-line treatment for locally advanced or metastatic non-squamous non-small cell lung cancer. Eur J Cancer 2014;50:1571-80.

32. Dowlati A, Chapman R, Subbiah S, et al. Randomized phase II trial of different schedules of administration of rebeccamycin analogue as second line therapy in non-small cell lung cancer. Invest New Drugs 2005;23:563-7.

33. Esteban E, González de Sande L, Fernández Y, et al. Prospective randomised phase II study of docetaxel versus paclitaxel administered weekly in patients with non-smallcell lung cancer previously treated with platinum-based chemotherapy. Ann Oncol 2003;14:1640-7.

34. Fanucchi MP, Fossella FV, Belt R, et al. Randomized phase II study of bortezomib alone and bortezomib in combination with docetaxel in previously treated advanced non-small-cell lung cancer. J Clin Oncol 2006;24:5025-33.

35. Fukuoka M, Yano S, Giaccone G, et al. Multi-institutional randomized phase II trial of gefitinib for previously treated patients with advanced non-small-cell lung cancer. J Clin Oncol 2003;21:2237-46.

36. Georgoulias V, Kouroussis C, Agelidou A, et al. Irinotecan plus gemcitabine vs irinotecan for the secondline treatment of patients with advanced non-smallcell lung cancer pretreated with docetaxel and cisplatin: a multicentre, randomised, phase II study. Br J Cancer 2004;91:482-8.

37. Georgoulias V, Agelidou A, Syrigos K, et al. Secondline treatment with irinotecan plus cisplatin vs cisplatin of patients with advanced non-small-cell lung cancer pretreated with taxanes and gemcitabine: a multicenter randomised phase II study. Br J Cancer 2005;93:763-9.

38. Gerber DE, Spigel DR, Giorgadze D, et al. Docetaxel Combined With Bavituximab in Previously Treated, Advanced Nonsquamous Non-Small-Cell Lung Cancer. Clin Lung Cancer 2016;17:169-76.

39. Gervais R, Ducolone A, Breton JL, et al. Phase II randomised trial comparing docetaxel given every 3 weeks with weekly schedule as second-line therapy in patients with advanced non-small-cell lung cancer (NSCLC). Ann Oncol 2005;16:90-6.

40. Gridelli C, Chella A, Valmadre G, et al. Second-line Erlotinib or Intermittent Erlotinib plus Docetaxel in Male Ex-smokers with Squamous NSCLC: The TALISMAN Randomized Trial. Anticancer Res 2016;36:6535-40.

41. Groen HJ, Socinski MA, Grossi F, et al. A randomized, double-blind, phase II study of erlotinib with or without sunitinib for the second-line treatment of metastatic non-small-cell lung cancer (NSCLC). Ann Oncol 
2013;24:2382-9.

42. Han B, Li K, Zhao Y, et al. Anlotinib as a third-line therapy in patients with refractory advanced non-smallcell lung cancer: a multicentre, randomised phase II trial (ALTER0302). Br. J. Cancer 2018;118:654-61.

43. Heigener DF, von Pawel J, Eschbach C, et al. Prospective, multicenter, randomized, independent-group, open-label phase II study to investigate the efficacy and safety of three regimens with two doses of sagopilone as second-line therapy in patients with stage IIIB or IV non-small-cell lung cancer. Lung Cancer 2013;80:319-25.

44. Heist RS, Wang X, Hodgson L, et al. CALGB 30704 (Alliance): A randomized phase II study to assess the efficacy of pemetrexed or sunitinib or pemetrexed plus sunitinib in the second-line treatment of advanced nonsmall-cell lung cancer. J Thorac Oncol 2014;9:214-21.

45. Herbst RS, O'Neill VJ, Fehrenbacher L, et al. Phase II study of efficacy and safety of bevacizumab in combination with chemotherapy or erlotinib compared with chemotherapy alone for treatment of recurrent or refractory non-small-cell lung cancer. J Clin Oncol 2007;25:4743-50.

46. Heudobler D, Schulz C, Fischer JR, et al. Pioglitazone and clarithromycin combined with metronomic lowdose chemotherapy versus nivolumab in patients with advanced non-small cell lung cancer treated in 2nd-line and beyond: outcomes from a randomized phase II trial (ModuLung). Ann Oncol 2019;30:v646-v647.

47. Heymach JV, Johnson BE, Prager D, et al. Randomized, placebo-controlled phase II study of vandetanib plus docetaxel in previously treated non-small-cell lung cancer. J Clin Oncol 2007;25:4270-7.

48. Ikezawa Y, Asahina H, Oizumi S, et al. A randomized phase II trial of erlotinib vs. S-1 as a third- or fourth-line therapy for patients with wild-type EGFR non-small cell lung cancer (HOT1002). Cancer Chemother Pharmacol 2017;80:955-63.

49. Jones $\mathrm{S}$, Thompson D, Barton J, et al. A randomized phase II trial of oral topotecan versus docetaxel in the secondline treatment of non-small-cell lung cancer. Clin. Lung Cancer 2008;9:154-9.

50. Juan O, Aparisi F, Sanchez-Hernandez A, et al. Intercalated Dosing Schedule of Erlotinib and Docetaxel as a Therapeutic Strategy to Avoid Antagonism and Optimize Its Benefits in Advanced Non-Small-Cell Lung Cancer. A Randomized Phase II Clinical Trial. Clin Lung Cancer 2015;16:193-9.

51. Kentepozidis N, Economopoulou P, Christofyllakis C, et al. Salvage treatment with irinotecan/cisplatin versus pemetrexed/cisplatin in patients with non-small cell lung cancer pre-treated with a non-platinum-based regimen in the first-line setting: a randomized phase II study of the Hellenic Oncology Research Group (HORG). Clin Transl Oncol 2017;19:317-25.

52. Kim ST, Uhm JE, Lee J, et al. Randomized phase II study of gefitinib versus erlotinib in patients with advanced nonsmall cell lung cancer who failed previous chemotherapy. Lung Cancer 2012;75:82-8.

53. Kim YS, Cho EK, Woo HS, et al. Randomized Phase II Study of Pemetrexed Versus Gefitinib in Previously Treated Patients with Advanced Non-small Cell Lung Cancer. Cancer Res Treat 2016;48:80-7.

54. Kim HR, Jang JS, Sun JM, et al. A randomized, phase II study of gefitinib alone versus nimotuzumab plus gefitinib after platinum-based chemotherapy in advanced nonsmall cell lung cancer (KCSG LU12-01). Oncotarget 2017;8:15943-51.

55. Lai CL, Tsai CM, Chiu CH, et al. Phase II randomized trial of tri-weekly versus days 1 and 8 weekly docetaxel as a second-line treatment of advanced non-small cell lung cancer. Jpn J Clin Oncol 2005;35:700-6.

56. Lee DH, Lee JS, Kim SW, et al. Three-arm randomised controlled phase 2 study comparing pemetrexed and erlotinib to either pemetrexed or erlotinib alone as secondline treatment for never-smokers with non-squamous nonsmall cell lung cancer. Eur J Cancer 2013;49:3111-21.

57. Levy BP, Giaccone G, Besse B, et al. Randomised phase 2 study of pembrolizumab plus CC-486 versus pembrolizumab plus placebo in patients with previously treated advanced non-small cell lung cancer. Eur J Cancer 2019;108:120-8.

58. Li N, Ou W, Yang H, et al. A randomized phase 2 trial of erlotinib versus pemetrexed as second-line therapy in the treatment of patients with advanced EGFR wild-type and EGFR FISH-positive lung adenocarcinoma. Cancer 2014;120:1379-86.

59. Lin Q, Meng FJ, Liu YE, et al. Phase II trial of capecitabine combined with docetaxel in previously treated patients with non-small cell lung cancer: A randomized controlled study. Oncol Lett 2012;3:761-6.

60. Liu Z, Wei Z, Hu Y, et al. A phase II open-label clinical study of comparing nab-paclitaxel with pemetrexed as second-line chemotherapy for patients with stage IIIB/IV non-small-cell lung cancer. Med Oncol 2015;32:216.

61. Lu S, Chang J, Liu X, et al. Randomized, DoubleBlind, Placebo-Controlled, Multicenter Phase II 
Study of Fruquintinib After Two Prior Chemotherapy

Regimens in Chinese Patients With Advanced

Nonsquamous NonSmall-Cell Lung Cancer. J Clin

Oncol 2018;36:1207-17.

62. Manegold C, Vansteenkiste J, Cardenal F, et al.

Randomized phase II study of three doses of the integrin inhibitor cilengitide versus docetaxel as second-line treatment for patients with advanced non-small-cell lung cancer. Invest. New Drugs 2013;31:175-82.

63. Morgensztern D, Cobo M, Aix SP, et al. ABOUND.2L+: A randomized phase 2 study of nanoparticle albuminbound paclitaxel with or without CC-486 as second-line treatment for advanced nonsquamous non-small cell lung cancer (NSCLC). Cancer 2018;124:4667-75.

64. Natale RB, Bodkin D, Govindan R, et al. Vandetanib versus gefitinib in patients with advanced non-smallcell lung cancer: results from a two-part, double-blind, randomized phase ii study. J Clin Oncol 2009;27:2523-9.

65. Natale R, Blackhall F, Kowalski D, et al. Evaluation of antitumor activity using change in tumor size of the survivin antisense oligonucleotide LY2181308 in combination with docetaxel for second-line treatment of patients with non-small-cell lung cancer: a randomized open-label phase II study. J Thorac Oncol 2014;9:1704-8.

66. Neal JW, Dahlberg SE, Wakelee HA, et al. Erlotinib, cabozantinib, or erlotinib plus cabozantinib as secondline or third-line treatment of patients with EGFR wildtype advanced non-small-cell lung cancer (ECOG-ACRIN 1512): a randomised, controlled, open-label, multicentre, phase 2 trial. Lancet Oncol 2016;17:1661-71.

67. Nishino K, Imamura F, Kumagai T, et al. A randomized phase II study of bevacizumab in combination with docetaxel or S-1 in patients with non-squamous non-smallcell lung cancer previously treated with platinum based chemotherapy (HANSHIN Oncology Group 0110). Lung Cancer 2015;89:146-53.

68. Pallis AG, Syrigos K, Kotsakis A, et al. Second-line paclitaxel/carboplatin versus vinorelbine/carboplatin in patients who have advanced non-small-cell lung cancer pretreated with non-platinum-based chemotherapy: a multicenter randomized phase II study. Clin. Lung Cancer 2011;12:100-5.

69. Parikh PM, Vaid A, Advani SH, et al. Randomized, double-blind, placebo-controlled phase II study of singleagent oral talactoferrin in patients with locally advanced or metastatic non-small-cell lung cancer that progressed after chemotherapy. J Clin Oncol 2011;29:4129-36.

70. Von Pawel J, Papai-Szekely Z, Vinolas N, et al.
A randomized phase 2 study of pemetrexed vs. pemetrexed+erlotinib in second-line treatment for locally advanced or metastatic, non-squamous NSCLC. Pneumologie 2012;66.

71. Pectasides D, Pectasides M, Farmakis D, et al. Comparison of docetaxel and docetaxel-irinotecan combination as second-line chemotherapy in advanced non-small-cell lung cancer: a randomized phase II trial. Ann Oncol 2005;16:294-9.

72. Quoix E, Lebeau B, Depierre A, et al. Randomised, multicentre phase II study assessing two doses of docetaxel (75 or $100 \mathrm{mg} / \mathrm{m} 2$ ) as second-line monotherapy for nonsmall-cell lung cancer. Ann Oncol 2004;15:38-44.

73. Ramalingam SS, Spigel DR, Chen D, et al. Randomized phase II study of erlotinib in combination with placebo or R1507, a monoclonal antibody to insulin-like growth factor-1 receptor, for advanced-stage non-small-cell lung cancer. J Clin Oncol 2011;29:4574-80.

74. Ramalingam SS, Blackhall F, Krzakowski M, et al. Randomized phase II study of dacomitinib (PF00299804), an irreversible pan-human epidermal growth factor receptor inhibitor, versus erlotinib in patients with advanced non-small-cell lung cancer. J Clin Oncol 2012;30:3337-44.

75. Ready N, Karaseva NA, Orlov SV, et al. Double-blind, placebo-controlled, randomized phase 2 study of the proapoptotic agent AT-101 plus docetaxel, in second-line non-small cell lung cancer. J Thorac Oncol 2011;6:781-5.

76. Reck M, Kaiser R, Eschbach C, et al. A phase II doubleblind study to investigate efficacy and safety of two doses of the triple angiokinase inhibitor BIBF 1120 in patients with relapsed advanced non-small-cell lung cancer. Ann Oncol 2011;22:1374-81.

77. Robinet G, Barlesi F, Fournel P, et al. Second-line therapy with gefitinib in combination with docetaxel for advanced non-small cell lung cancer: a phase II randomized study. Target Oncol 2007;2:63-71.

78. Ross HJ, Hart LL, Swanson PM, et al. A randomized, multicenter study to determine the safety and efficacy of the immunoconjugate SGN-15 plus docetaxel for the treatment of non-small cell lung carcinoma. Lung Cancer 2006;54:69-77.

79. Scagliotti GV, Bondarenko I, Ciuleanu TE, et al.A randomized phase 2 study of abemaciclib versus docetaxel in patients with stage IV squamous non-small cell lung cancer (sqNSCLC) previously treated with platinum-based chemotherapy. J Clin Oncol 2018;35:9059.

80. Schiller JH, von Pawel J, Schütt P, et al. Pemetrexed 
with or without matuzumab as second-line treatment for patients with stage IIIB/IV non-small cell lung cancer. J Thorac Oncol 2010;5:1977-85.

81. Segawa Y, Kiura K, Hotta K, et al. A randomized phase II study of a combination of docetaxel and S-1 versus docetaxel monotherapy in patients with nonsmall cell lung cancer previously treated with platinumbased chemotherapy: results of Okayama Lung Cancer Study Group (OLCSG) Trial 0503. J Thorac Oncol 2010;5:1430-4.

82. Smit EF, Burgers SA, Biesma B, et al. Randomized phase II and pharmacogenetic study of pemetrexed compared with pemetrexed plus carboplatin in pretreated patients with advanced non-small-cell lung cancer. J Clin Oncol 2009;27:2038-45.

83. Soria JC, Fülöp A, Maciel C, et al. SELECT-2: A phase II, double-blind, randomized, placebo-controlled study to assess the efficacy of selumetinib plus docetaxel as a second-line treatment of patients with advanced or metastatic non-small-cell lung cancer. Ann Oncol 2017;28:3028-36.

84. Spigel DR, Burris HA, 3rd, Greco FA, et al. Erlotinib plus either pazopanib or placebo in patients with previously treated advanced non-small cell lung cancer: A randomized, placebo-controlled phase 2 trial with correlated serum proteomic signatures. Cancer 2018;124:2355-64.

85. Spigel DR, Burris HA 3rd, Greco FA, et al. Randomized, double-blind, placebo-controlled, phase II trial of sorafenib and erlotinib or erlotinib alone in previously treated advanced non-small-cell lung cancer. J Clin Oncol 2011;29:2582-9.

86. Talbot DC, Von Pawel J, Cattell E, et al. A randomized phase II pharmacokinetic and pharmacodynamic study of indisulamas second-line therapy in patients with advanced non-small cell lung cancer. Clin Cancer Res 2007;13:1816-22.

87. Tan EH, Goss GD, Salgia R, et al. Phase 2 Trial of Linifanib (ABT-869) in Patients with Advanced Non-small Cell Lung Cancer. J Thorac Oncol 2011;6:1418-25.

88. Wachters FM, Groen HJM, Biesma B, et al. A randomised phase II trial of docetaxel vs docetaxel and irinotecan in patients with stage IIIb-IV non-small-cell lung cancer who failed first-line treatment. Br J Cancer 2005;92:15-20.

89. Waller CF, Vynnychenko I, Bondarenko I, et al. An openlabel, multicenter, randomized phase Ib/II study of eribulin mesylate administered in combination with pemetrexed versus pemetrexed alone as second-line therapy in patients with advanced nonsquamous non-small-cell lung cancer. Clin Lung Cancer 2015;16:92-9.

90. Wu Y, Feng J, Hu W, Luo Q. A randomized placebocontrolled clinical study of nab-paclitaxel as second-line chemotherapy for patients with advanced non-small cell lung cancer in China. Biosci Rep 2017;37:BSR20170020.

91. Yoh K, Hosomi Y, Kasahara K, et al. A randomized, double-blind, phase II study of ramucirumab plus docetaxel vs placebo plus docetaxel in Japanese patients with stage IV non-small cell lung cancer after disease progression on platinum-based therapy. Lung Cancer 2016;99:186-93.

92. Zhang Y, Gao C, Qu W, et al. A Randomized Phase II Study of Erlotinib Plus Nab-Paclitaxel Versus Erlotinib Alone as Second-Line Therapy for Chinese Patients with Advanced EGFR Wild-Type Non-Small-Cell Lung Cancer. Cancer Invest 2015;33:241-5.

93. Zhou Q, Cheng Y, Yang JJ, et al. Pemetrexed versus gefitinib as a second-line treatment in advanced nonsquamous nonsmall-cell lung cancer patients harboring wild-type EGFR (CTONG0806): a multicenter randomized trial. Ann Oncol 2014;25:2385-91. 
Table S1 Preferred Reporting Items for Systematic Reviews and Meta-Analyses checklist

\begin{tabular}{|c|c|c|c|}
\hline Section/topic & \# & Checklist item & Reported on \\
\hline \multicolumn{4}{|l|}{ TITLE } \\
\hline Title & 1 & Identify the report as a systematic review, meta-analysis, or both. & Front page \\
\hline \multicolumn{4}{|l|}{ ABSTRACT } \\
\hline $\begin{array}{l}\text { Structured } \\
\text { summary }\end{array}$ & 2 & $\begin{array}{l}\text { Provide a structured summary including, as applicable: background; objectives; data } \\
\text { sources; study eligibility criteria, participants, and interventions; study appraisal and } \\
\text { synthesis methods; results; limitations; conclusions and implications of key findings; } \\
\text { systematic review registration number. }\end{array}$ & Abstract \\
\hline \multicolumn{4}{|l|}{ INTRODUCTION } \\
\hline Rationale & 3 & Describe the rationale for the review in the context of what is already known. & $\begin{array}{l}\text { Introduction, 1st } \\
\text { paragraph }\end{array}$ \\
\hline Objectives & 4 & $\begin{array}{l}\text { Provide an explicit statement of questions being addressed with reference to } \\
\text { participants, interventions, comparisons, outcomes, and study design (PICOS). }\end{array}$ & $\begin{array}{l}\text { Introduction, 2nd } \\
\text { paragraph }\end{array}$ \\
\hline \multicolumn{4}{|l|}{ METHODS } \\
\hline $\begin{array}{l}\text { Protocol and } \\
\text { registration }\end{array}$ & 5 & $\begin{array}{l}\text { Indicate if a review protocol exists, if and where it can be accessed (e.g., Web address), } \\
\text { and, if available, provide registration information including registration number. }\end{array}$ & $\begin{array}{l}\text { Methods, Study } \\
\text { overview }\end{array}$ \\
\hline Eligibility criteria & 6 & $\begin{array}{l}\text { Specify study characteristics (e.g., PICOS, length of follow-up) and report } \\
\text { characteristics (e.g., years considered, language, publication status) used as criteria } \\
\text { for eligibility, giving rationale. }\end{array}$ & $\begin{array}{l}\text { Methods, Study } \\
\text { selection }\end{array}$ \\
\hline $\begin{array}{l}\text { Information } \\
\text { sources }\end{array}$ & 7 & $\begin{array}{l}\text { Describe all information sources (e.g., databases with dates of coverage, contact with } \\
\text { study authors to identify additional studies) in the search and date last searched. }\end{array}$ & $\begin{array}{l}\text { Methods, Study } \\
\text { search }\end{array}$ \\
\hline Search & 8 & $\begin{array}{l}\text { Present full electronic search strategy for at least one database, including any limits } \\
\text { used, such that it could be repeated. }\end{array}$ & Table S2 \\
\hline Study selection & 9 & $\begin{array}{l}\text { State the process for selecting studies (i.e., screening, eligibility, included in systematic } \\
\text { review, and, if applicable, included in the meta-analysis). }\end{array}$ & $\begin{array}{l}\text { Methods, Study } \\
\text { search }\end{array}$ \\
\hline $\begin{array}{l}\text { Data collection } \\
\text { process }\end{array}$ & 10 & $\begin{array}{l}\text { Describe method of data extraction from reports (e.g., piloted forms, independently, in } \\
\text { duplicate) and any processes for obtaining and confirming data from investigators. }\end{array}$ & $\begin{array}{l}\text { Methods, Data } \\
\text { extraction }\end{array}$ \\
\hline Data items & 11 & $\begin{array}{l}\text { List and define all variables for which data were sought (e.g., PICOS, funding sources) } \\
\text { and any assumptions and simplifications made. }\end{array}$ & $\begin{array}{l}\text { Methods, Data } \\
\text { extraction }\end{array}$ \\
\hline $\begin{array}{l}\text { Risk of bias in } \\
\text { individual studies }\end{array}$ & 12 & $\begin{array}{l}\text { Describe methods used for assessing risk of bias of individual studies (including } \\
\text { specification of whether this was done at the study or outcome level), and how this } \\
\text { information is to be used in any data synthesis. }\end{array}$ & $\begin{array}{l}\text { Methods, Assessmen } \\
\text { of risk of bias }\end{array}$ \\
\hline $\begin{array}{l}\text { Summary } \\
\text { measures }\end{array}$ & 13 & State the principal summary measures (e.g., risk ratio, difference in means). & Methods, Outcomes \\
\hline $\begin{array}{l}\text { Synthesis of } \\
\text { results }\end{array}$ & 14 & $\begin{array}{l}\text { Describe the methods of handling data and combining results of studies, if done, } \\
\left.\text { including measures of consistency (e.g., } I^{2}\right) \text { for each meta-analysis. }\end{array}$ & $\begin{array}{l}\text { Methods, Statistics } \\
\text { 1st paragraph }\end{array}$ \\
\hline $\begin{array}{l}\text { Risk of bias across } \\
\text { studies }\end{array}$ & 15 & $\begin{array}{l}\text { Specify any assessment of risk of bias that may affect the cumulative evidence (e.g., } \\
\text { publication bias, selective reporting within studies). }\end{array}$ & $\begin{array}{l}\text { Methods, Statistics } \\
\text { 1st paragraph }\end{array}$ \\
\hline $\begin{array}{l}\text { Additional } \\
\text { analyses }\end{array}$ & 16 & $\begin{array}{l}\text { Describe methods of additional analyses (e.g., sensitivity or subgroup analyses, meta- } \\
\text { regression), if done, indicating which were pre-specified. }\end{array}$ & $\begin{array}{l}\text { Methods, Statistics } \\
\text { 2nd paragraph }\end{array}$ \\
\hline \multicolumn{4}{|l|}{ RESULTS } \\
\hline Study selection & 17 & $\begin{array}{l}\text { Give numbers of studies screened, assessed for eligibility, and included in the review, } \\
\text { with reasons for exclusions at each stage, ideally with a flow diagram. }\end{array}$ & Results, Study search \\
\hline $\begin{array}{l}\text { Study } \\
\text { characteristics }\end{array}$ & 18 & $\begin{array}{l}\text { For each study, present characteristics for which data were extracted (e.g., study size, } \\
\text { PICOS, follow-up period) and provide the citations. }\end{array}$ & $\begin{array}{l}\text { Results, Study } \\
\text { characteristics }\end{array}$ \\
\hline $\begin{array}{l}\text { Risk of bias within } \\
\text { studies }\end{array}$ & 19 & $\begin{array}{l}\text { Present data on risk of bias of each study and, if available, any outcome level } \\
\text { assessment (see item 12). }\end{array}$ & Table S3 \\
\hline $\begin{array}{l}\text { Results of } \\
\text { individual studies }\end{array}$ & 20 & $\begin{array}{l}\text { For all outcomes considered (benefits or harms), present, for each study: (a) simple } \\
\text { summary data for each intervention group (b) effect estimates and confidence intervals, } \\
\text { ideally with a forest plot. }\end{array}$ & Table S4 \\
\hline $\begin{array}{l}\text { Synthesis of } \\
\text { results }\end{array}$ & 21 & $\begin{array}{l}\text { Present results of each meta-analysis done, including confidence intervals and } \\
\text { measures of consistency. [Meta-analysis was not conducted but the data for primary } \\
\text { analysis including confidence intervals and consistency within analyses were } \\
\text { presented] }\end{array}$ & Figure 2 \\
\hline $\begin{array}{l}\text { Risk of bias across } \\
\text { studies }\end{array}$ & 22 & Present results of any assessment of risk of bias across studies (see Item 15). & Figure S1 \\
\hline Additional analysis & 23 & $\begin{array}{l}\text { Give results of additional analyses, if done (e.g., sensitivity or subgroup analyses, } \\
\text { meta-regression [see Item 16]). }\end{array}$ & Figure 3 \\
\hline \multicolumn{4}{|l|}{ DISCUSSION } \\
\hline $\begin{array}{l}\text { Summary of } \\
\text { evidence }\end{array}$ & 24 & $\begin{array}{l}\text { Summarize the main findings including the strength of evidence for each main } \\
\text { outcome; consider their relevance to key groups (e.g., healthcare providers, users, and } \\
\text { policy makers). }\end{array}$ & $\begin{array}{l}\text { Discussion 1st } \\
\text { paragraph }\end{array}$ \\
\hline Limitations & 25 & $\begin{array}{l}\text { Discuss limitations at study and outcome level (e.g., risk of bias), and at review-level } \\
\text { (e.g., incomplete retrieval of identified research, reporting bias). }\end{array}$ & $\begin{array}{l}\text { Discussion 6th } \\
\text { paragraph }\end{array}$ \\
\hline Conclusions & 26 & $\begin{array}{l}\text { Provide a general interpretation of the results in the context of other evidence, and } \\
\text { implications for future research. }\end{array}$ & $\begin{array}{l}\text { Discussion } 7 \text { th } \\
\text { paragraph }\end{array}$ \\
\hline \multicolumn{4}{|l|}{ FUNDING } \\
\hline Funding & 27 & $\begin{array}{l}\text { Describe sources of funding for the systematic review and other support (e.g., supply } \\
\text { of data); role of funders for the systematic review. }\end{array}$ & Footnote \\
\hline
\end{tabular}


Table S2 Search strategies

\begin{tabular}{|c|c|}
\hline Database and search formula & $\mathrm{N}$ \\
\hline $\begin{array}{l}\text { (Non Small Cell Lung Cancer OR Non Small Cell Lung Carcinoma OR NSCLC OR Adenocarcinoma of Lung OR } \\
\text { Squamous carcinoma of lung) AND (Recurrent OR Recurrence OR relapsed OR Advanced OR Advance OR Metastatic } \\
\text { OR Metastasis OR Stage IV OR Stage III OR Stage four OR Stage three) AND (Phase II OR Phase two OR Phase 2) } \\
\text { AND (Randomized OR Randomised OR Randomly OR RCT) AND (2nd line OR Second line OR 3rd line OR Third line } \\
\text { OR later line) }\end{array}$ & \\
\hline Web of Science & 432 \\
\hline $\begin{array}{l}\text { TS=((Non Small Cell Lung Cancer OR Non Small Cell Lung Carcinoma OR NSCLC OR Adenocarcinoma of Lung OR } \\
\text { Squamous carcinoma of lung) AND (Recurrent OR Recurrence OR relapsed OR Advanced OR Advance OR Metastatic } \\
\text { OR Metastasis OR Stage IV OR Stage III OR Stage four OR Stage three) AND (Phase II OR Phase two OR Phase 2) } \\
\text { AND (Randomized OR Randomised OR Randomly OR RCT) AND (2nd line OR Second line OR 3rd line OR Third line } \\
\text { OR later line)) }\end{array}$ & \\
\hline \#3 \#1 AND \#2 & \\
\hline Limit English & \\
\hline Cochrane & 584 \\
\hline $\begin{array}{l}\text { \#1 (Non Small Cell Lung Cancer OR Non Small Cell Lung Carcinoma OR NSCLC OR Adenocarcinoma of Lung OR } \\
\text { Squamous carcinoma of lung) AND (Recurrent OR Recurrence OR relapsed OR Advanced OR Advance OR Metastatic } \\
\text { OR Metastasis OR Stage IV OR Stage III OR Stage four OR Stage three) AND (Phase II OR Phase two OR Phase 2) } \\
\text { AND (Randomized OR Randomised OR Randomly OR RCT) AND (2nd line OR Second line OR 3rd line OR Third line } \\
\text { OR later line) }\end{array}$ & \\
\hline $\begin{array}{l}\text { ('non small cell lung cancer'/exp OR 'non small cell lung cancer' OR (non AND small AND ('cell'/exp OR cell) AND } \\
\text { ('lung'/exp OR lung) AND ('cancer'/exp OR cancer)) OR 'non small cell lung carcinoma'/exp OR 'non small cell } \\
\text { lung carcinoma' OR (non AND small AND ('cell'/exp OR cell) AND ('lung'/exp OR lung) AND ('carcinoma'/exp OR } \\
\text { carcinoma)) OR nsclc OR 'adenocarcinoma of lung'/exp OR 'adenocarcinoma of lung' OR (('adenocarcinoma'// } \\
\text { exp OR adenocarcinoma) AND of AND ('lung'/exp OR lung)) OR 'squamous carcinoma of lung' OR (squamous } \\
\text { AND ('carcinoma'/exp OR carcinoma) AND of AND ('lung'/exp OR lung))) AND (recurrent OR 'recurrence'/exp OR } \\
\text { recurrence OR relapsed OR advancedOR 'advance'/exp OR advance OR metastatic OR 'metastasis'/exp OR } \\
\text { metastasis OR 'stage iv' OR (stage AND iv) OR 'stage iii' OR (stage AND iii) OR 'stage four' OR (stage AND four) OR } \\
\text { 'stage three' OR (stage AND three)) AND ('phase ii' OR (phase AND ii) OR 'phase two' OR (phase AND two) OR 'phase } \\
2 \text { ' OR (phase AND 2)) AND (randomized OR randomised OR randomly OR rct) AND ('2nd line' OR (2nd AND ('line'/) } \\
\text { exp OR line)) OR 'second line' OR (second AND ('line'/exp OR line)) OR '3rd line' OR (3rd AND ('line'/exp OR line)) OR } \\
\text { 'third line' OR (third AND ('line'/exp OR line)) OR 'later line' OR (later AND ('line'/exp OR line))) AND ('phase ii':ti OR } \\
\text { 'phase two':ti OR 'phase 2':ti) AND (randomized:ti OR randomised:ti OR randomly:ti OR rct:ti) AND ('2nd line':ti OR } \\
\text { 'second line':ti OR '3rd line':ti OR 'third line':ti OR 'later line':ti) AND [english]/lim }\end{array}$ & \\
\hline Total & 1425 \\
\hline
\end{tabular}


Table S3 Cochrane risk of bias

\begin{tabular}{lcccccc}
\hline Author (year) & $\begin{array}{c}\text { Random sequence } \\
\text { generation } \\
\text { (selection bias) }\end{array}$ & $\begin{array}{c}\text { Allocation } \\
\text { concealment } \\
\text { (selection bias) }\end{array}$ & $\begin{array}{c}\text { Blinding of } \\
\text { participants } \\
\text { and personnel } \\
\text { (performance bias) }\end{array}$ & $\begin{array}{c}\text { Blinding of } \\
\text { outcome } \\
\text { assessment } \\
\text { (detection bias) }\end{array}$ & $\begin{array}{c}\text { Incomplete } \\
\text { outcome data } \\
\text { addressed } \\
\text { (attrition bias) }\end{array}$ & $\begin{array}{c}\text { Selective } \\
\text { reporting } \\
\text { (reporting bias) }\end{array}$ \\
\hline Aerts (2013) (22) & $\mathrm{L}$ & $\mathrm{L}$ & $\mathrm{H}$ & $\mathrm{H}$ & $\mathrm{H}$ & $\mathrm{L}$
\end{tabular}

Ardizzoni (2012)

GOIRC02-2006 (23)

Ardizzoni (2012) NVALT7 (23)

Belvedere (2011) (24)

Bergqvist (2017) (25)

Blumenschein (2015) (26)

Bradbury (2018) (27)

Chiappori (2010) (28)

Cortinovis (2008) (29)

Cufer (2006) (30)

Dittrich (2014) (31)

Dowlati (2005) (32)

Esteban (2003) (33)

Fanucchi (2006) (34)

Fehrenbacher (2016) (17)

Fukuoka (2003) (35)

Georgoulias (2004) (36)

Georgoulias (2005) (37)

Gerber (2016) (38)

Gervais (2005) (39)

Gridelli (2016) (40)

Groen (2013) (41)

Han (2018) (42)

Heigener (2013) (43)

Heist (2014) (44)

Herbst (2007) (45)

Heudobler (2019) (46)

Heymach (2007) (47)

Ikezawa (2017) (48)

Jones (2008) (49)

Juan (2015) (50)

Kentepozidis (2017) (51)

Kim (2012) (52)

Kim (2016) (53)

Kim (2017) (54)

Lai (2005) (55)

Lee (2013) (56)

Levy (2019) (57)

Li (2014) (58)

Lin (2012) (59)

Liu (2015) (60)

Lu (2018) (61)

Manegold (2013) (62)

Morgensztern (2018) (63)

Natale (2009) (64)

Natale (2014) (65)

Neal (2016) (66)

Nishino (2015) (67)

Pallis (2011) (68)

Parikh (2011) (69)

Pawel (2012) (70)

Pectasides (2005) (71)

Quoix (2004) (72)

Ramalingam (2011) (73)

Ramalingam (2012) (74)

Ready (2011) (75)

Reck (2011) (76)

Robinet (2007) (77)

Ross (2006) (78)

Scagliotti (2018) (79)

Schiller (2010) (80)

Segawa (2010) (81)

Smit (2009) (82)

Soria (2017) (83)

Spigel (2018) (84)

Spigel (2011) (85)

Talbot (2007) (86)

Tan (2011) (87)

Wachters (2005) (88)

Waller (2015) (89)

Wu (2017) (90)

Yoh (2016) (91)

Zhang (2015) (92)

Zhou (2014) (93)

H/U/L: High/Unclear/Low risk of bias. 


\begin{tabular}{|c|c|c|c|c|c|}
\hline Author (year) & HRos & ORorr & $\triangle \mathrm{ORR}(\%)$ & ORder & $\triangle \mathrm{DCR}(\%)$ \\
\hline Aerts (2013) & 1.49 & 0.50 & -6 & 0.56 & -14 \\
\hline $\begin{array}{l}\text { Ardizzoni (2012) } \\
\text { GOIRC02-2006 }\end{array}$ & 1.03 & 0.99 & 0 & 0.77 & -6 \\
\hline $\begin{array}{l}\text { Ardizzoni (2012) } \\
\text { NVALT7 }\end{array}$ & 1.19 & 0.30 & -11 & 0.84 & -4 \\
\hline Belvedere (2011) & 0.81 & 2.88 & 12 & 3.86 & 32 \\
\hline Bergqvist (2017) & 0.90 & 0.06 & -12 & 0.55 & -12 \\
\hline Blumenschein (2015) & 0.97 & 1.00 & 0 & 1.10 & 2 \\
\hline Bradbury (2018) & 0.98 & 0.97 & 0 & 1.10 & 2 \\
\hline Chiappori (2010) & 0.70 & 1.52 & 1 & 1.00 & 0 \\
\hline Cortinovis (2008) & 1.00 & 0.91 & 0 & 2.02 & 17 \\
\hline Cufer (2006) & 0.97 & 0.96 & 0 & 1.20 & 4 \\
\hline Dittrich (2014) & 1.47 & 0.59 & -6 & 0.87 & -3 \\
\hline Dowlati (2005) & 1.34 & 1.00 & 0 & 2.20 & 19 \\
\hline Esteban (2003) & 1.21 & 5.48 & 11 & 0.72 & -7 \\
\hline Fanucchi (2006) & 0.95 & 0.91 & -1 & 0.36 & -24 \\
\hline Fehrenbacher (2016) & 0.73 & 0.99 & 0 & NA & NA \\
\hline Fukuoka (2003) & 0.90 & 0.96 & -1 & 1.12 & 3 \\
\hline Georgoulias (2004) & 0.91 & 5.17 & 14 & 1.94 & 15 \\
\hline Georgoulias (2005) & 1.02 & 3.75 & 15 & 1.10 & 2 \\
\hline Gerber (2016) & 1.52 & 0.62 & -6 & 0.82 & -5 \\
\hline Gervais (2005) & 0.83 & 1.55 & 2 & 1.40 & 7 \\
\hline Gridelli (2016) & 1.24 & 0.33 & -5 & 1.22 & 5 \\
\hline Groen (2013) & 1.07 & 1.57 & 2 & NA & NA \\
\hline Han (2018) & 0.78 & 13.72 & 10 & 10.83 & 52 \\
\hline Heigener (2013) & 0.74 & 0.46 & -5 & 0.95 & -1 \\
\hline Heist (2014) & 0.71 & 0.81 & -3 & 1.45 & 9 \\
\hline Herbst (2007) & 1.41 & 0.97 & 0 & 0.58 & -13 \\
\hline Heudobler (2019) & 0.86 & 4.73 & 10 & NA & NA \\
\hline Heymach (2007) & 0.71 & 1.60 & 8 & 2.86 & 20 \\
\hline Ikezawa (2017) & 1.32 & 0.94 & -1 & 0.36 & -25 \\
\hline Jones (2008) & 0.81 & 0.97 & 0 & 0.86 & -4 \\
\hline Juan (2015) & 0.70 & 0.33 & -6 & 1.60 & 11 \\
\hline Kentepozidis (2017) & 1.64 & 0.77 & -4 & 0.82 & -5 \\
\hline Kim (2012) & 2.14 & 1.40 & 8 & 1.35 & 6 \\
\hline Kim (2016) & 1.05 & 1.61 & 4 & 1.47 & 9 \\
\hline Kim (2017) & 0.86 & 0.72 & -5 & 0.66 & -10 \\
\hline Lai (2005) & 1.00 & 0.43 & -12 & 1.17 & 4 \\
\hline Lee (2013) & 0.69 & 3.72 & 19 & 0.86 & -4 \\
\hline Levy (2019) & 1.38 & 1.46 & 5 & 0.54 & -13 \\
\hline Li (2014) & 1.01 & 2.79 & 12 & 1.10 & 2 \\
\hline Lin (2012) & 0.75 & 1.10 & 1 & 1.14 & 2 \\
\hline Liu (2015) & 1.23 & 0.71 & -4 & 0.65 & -10 \\
\hline Lu (2018) & 0.76 & 9.69 & 13 & 34.18 & 51 \\
\hline Manegold (2013) & 1.51 & 1.03 & 0 & 0.39 & -11 \\
\hline Morgensztern (2018) & 1.70 & 0.81 & -3 & 0.91 & -2 \\
\hline Natale (2009) & 0.84 & 0.13 & -7 & 0.64 & -10 \\
\hline Natale (2014) & 1.15 & 3.65 & 4 & NA & NA \\
\hline Neal (2016) & 1.47 & 0.23 & -8 & 0.15 & -42 \\
\hline Nishino (2015) & 1.25 & 11.00 & 18 & 1.00 & 0 \\
\hline Pallis (2011) & 0.92 & 2.75 & 11 & 1.67 & 12 \\
\hline Parikh (2011) & 0.68 & 2.31 & 2 & 1.94 & 14 \\
\hline Pawel (2012) & 1.47 & 0.59 & -6 & 0.88 & -3 \\
\hline Pectasides (2005) & 1.12 & 0.62 & -9 & 0.43 & -12 \\
\hline Quoix (2004) & 1.32 & 2.93 & 2 & 0.77 & -6 \\
\hline Ramalingam (2011) & 1.19 & 1.02 & 0 & 1.03 & 1 \\
\hline Ramalingam (2012) & 0.80 & 3.65 & 12 & 2.42 & 15 \\
\hline Ready (2011) & 0.82 & 2.00 & 2 & 1.04 & 1 \\
\hline Reck (2011) & 1.44 & 0.32 & -3 & 0.95 & -1 \\
\hline Robinet (2007) & 0.83 & 0.73 & -2 & 2.79 & 25 \\
\hline Ross (2006) & 0.81 & 0.20 & -16 & 1.14 & 3 \\
\hline Scagliotti (2018) & 1.33 & 0.11 & -18 & 0.58 & -13 \\
\hline Schiller (2010) & 1.49 & 0.22 & -12 & 1.13 & 3 \\
\hline Segawa (2010) & 0.42 & 1.36 & 5 & 1.20 & 4 \\
\hline Smit (2009) & 0.85 & 3.29 & 11 & 1.19 & 4 \\
\hline Soria (2017) & 0.83 & 2.26 & 15 & NA & NA \\
\hline Spigel (2018) & 0.99 & 2.36 & 6 & 1.54 & 10 \\
\hline Spigel (2011) & 0.89 & 0.72 & -3 & 1.90 & 16 \\
\hline Talbot (2007) & 1.04 & NA & NA & 1.71 & 11 \\
\hline Tan (2011) & 0.81 & 0.44 & -4 & NA & NA \\
\hline Wachters (2005) & 1.09 & 1.80 & 6 & 1.43 & 9 \\
\hline Waller (2015) & 1.00 & 1.04 & 1 & 1.74 & 12 \\
\hline Wu (2017) & 1.41 & 0.19 & -15 & 0.16 & -37 \\
\hline Yoh (2016) & 0.86 & 1.79 & 10 & 1.58 & 9 \\
\hline Zhang (2015) & 0.68 & 2.19 & 15 & 2.39 & 20 \\
\hline Zhou (2014) & 0.72 & 0.96 & 0 & 3.64 & 31 \\
\hline
\end{tabular}

HRos: hazard ratio of overall survival. ORorr: odds ratio of objective response rate. $\triangle \mathrm{ORR}$ : objective response rate difference. ORdcr: odds ratio of disease control rate. $\triangle \mathrm{DCR}$ : disease control rate difference. NA: not available. 


\section{Objective response rate (ORR)}

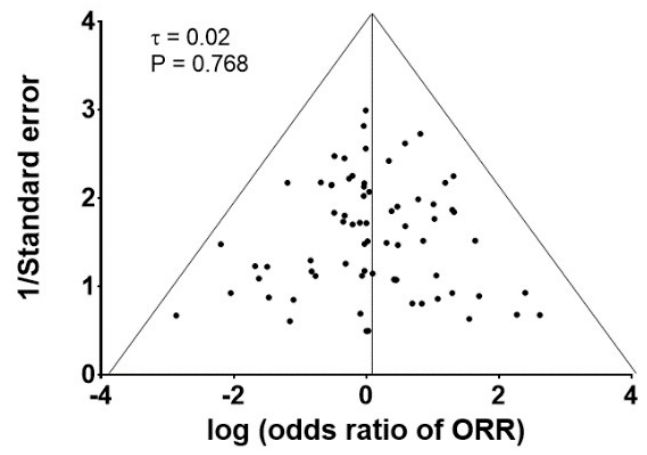

Disease control rate (DCR)

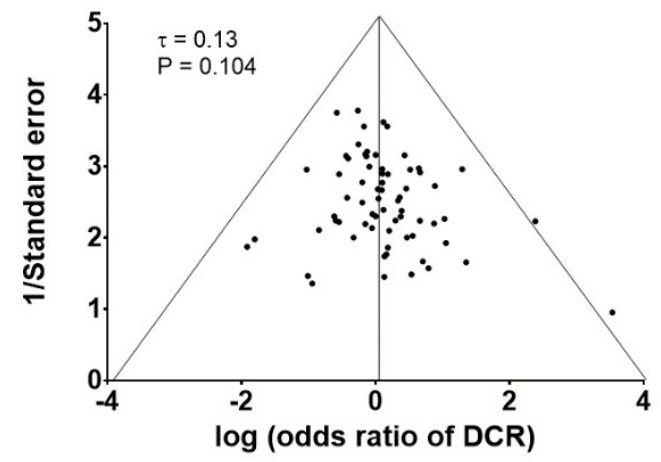

Figure S1 Funnel plots for objective response rate (ORR) and disease control rate (DCR). Begg-Kendall test was applied for publication bias assessment.

ORR difference

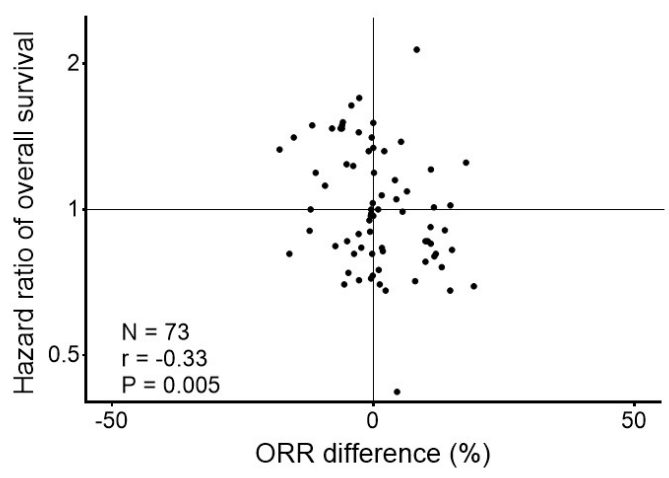

DCR difference

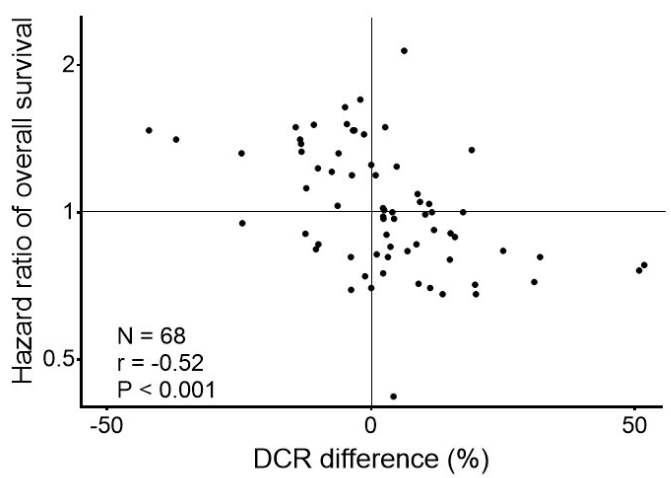

Figure S2 Trial-level surrogacy of objective response rate (ORR) difference and disease control rate (DCR) difference. N: number of trials. r: Spearman's rank correlation coefficient. A correlation coefficient was interpreted as follows: $|\mathrm{r}|<0.2$, no correlation; $0.2<|\mathrm{r}|<0.4$, weak correlation; $0.4<|\mathrm{r}|<0.6$, moderate correlation; $0.6<|\mathrm{r}|<0.8$, strong correlation; and $0.8<|\mathrm{r}|$, excellent correlation. 